OPEN ACCESS

Edited by:

Aras Petrulis,

Georgia State University,

United States

Reviewed by:

Deborah Kurrasch,

University of Calgary, Canada

Tatsushi Onaka,

Jichi Medical University, Japan

${ }^{*}$ Correspondence: Heather B. Patisaul

hbpatisa@ncsu.edu

Specialty section:

This article was submitted to Neuroendocrine Science, a section of the journal Frontiers in Endocrinology

Received: 18 April 2017 Accepted: 31 May 2017

Published: 19 June 2017

Citation:

Patisaul HB (2017) Endocrine Disruption of Vasopressin Systems and Related Behaviors.

Front. Endocrinol. 8:134. doi: 10.3389/fendo.2017.00134

\section{Endocrine Disruption of Vasopressin Systems and Related Behaviors}

\author{
Heather B. Patisaul* \\ Department of Biological Sciences, Center for Human Health and the Environment, NC State University, Raleigh, NC, \\ United States
}

Endocrine disrupting chemicals (EDCs) are chemicals that interfere with the organizational or activational effects of hormones. Although the vast majority of the EDC literature focuses on steroid hormone signaling related impacts, growing evidence from a myriad of species reveals that the nonapeptide hormones vasopressin (AVP) and oxytocin (OT) may also be EDC targets. EDCs shown to alter pathways and behaviors coordinated by AVP and/or OT include the plastics component bisphenol A (BPA), the soy phytoestrogen genistein (GEN), and various flame retardants. Many effects are sex specific and likely involve action at nuclear estrogen receptors. Effects include the elimination or reversal of well-characterized sexually dimorphic aspects of the AVP system, including innervation of the lateral septum and other brain regions critical for social and other nonreproductive behaviors. Disruption of magnocellular AVP function has also been reported in rats, suggesting possible effects on hemodynamics and cardiovascular function.

Keywords: bisphenol, oxytocin, sex differences, EDC, genistein, soy, social, anxiety, estrogens

Endocrine disrupting chemicals (EDCs) have garnered considerable attention over the past few decades, partly because of their omnipresence, but also because of rapidly compounding evidence that exposure, particularly during critical windows of development, is likely contributing to increasing incidence of multiple chronic diseases. Because, historically, EDC research has focused on steroid hormone disruption, especially estrogen and androgen disruption, EDCs are most often thought of in the context of reproductive disorders including infertility, genital malformations, accelerated puberty, and reproductive cancer. But the concept of endocrine disruption is far more broadly inclusive of other hormones and their targets, including the neuropeptide hormones vasopressin (AVP) and oxytocin (OT).

Broadly, AVP and OT are found only in mammals, are structurally similar, and evolutionarily derived from the pituitary hormone, vasotocin (VT). Magnocellular AVP and OT are axonally released into the periphery from the paraventricular and supraoptic nuclei (PVN and SON) via the neurohypophysis and coordinate a range of physiological processes, including uterine contractions, milk letdown, blood pressure, thermoregulation, and osmotic balance. The parvocellular system sends projections to the median eminence and throughout the brain and is sexually dimorphic, steroid hormone sensitive, and fundamental for the coordination of affiliative and social behaviors including courtship, pair bonding, empathy, reciprocity, trust, and context-specific aggression (1-4). In addition, populations of AVP/OT-releasing neurons have been identified in other areas of the hypothalamus and in extrahypothalamic structures such as the medial amygdala (5). OT binds to the OT receptor (OTR), and AVP binds to one of two AVP receptor (AVPR) subtypes: AVPR1A or AVPR1B, the central distribution of which can differ substantially by sex, age, and species (5). Differences in the region-specific distribution of AVPRs and/or OTRs have been linked to individual and species variation in prosocial phenotypes including social attachment, parental behavior, and 
social anxiety, as have genetic polymorphisms in AVP, OT, and/or their receptors. The anatomical and functional features of AVP/ OT neuronal subpopulations are beyond the scope of this review and detailed elsewhere $(6,7)$.

Centrally, the actions of OT and AVP largely overlap, albeit with some sexual dimorphisms, and these redundancies are not surprising given their relatively recent evolutionary divergence (summarized in Table 1). They can also have independent and even opposing effects. For example OT, but not AVP, appears to be critical for the extinction of social fear and promoting social interaction via enhancement of social preference suppression and social anxiety (8). Emerging evidence also suggests OT may suppress food intake and increase energy expenditure (9). Critically, opposing effects of AVP and OT refine the control of emotional behavior, and dysregulation of either can result in psychopathology. In general, central OT is anxiolytic, antidepressive, and prosocial, whereas AVP is anxiogenic and can heighten depressive-type behaviors (8). Consequently, there is concern that endocrine disruption of central AVP and/or OT function could adversely impact emotional control, and possibly heighten risk of psychosocial disorders. AVP and OT systems are also anatomically and functionally linked with catecholaminergic systems (10) and the mesolimbic dopamine system (1). That AVP and OT are fundamental to such a wide range of functions and behaviors indicates that disruption by EDCs could have profound and multifaceted effects throughout the neuroendocrine system. This review presents what is currently know about EDCs, AVP/ OT systems, and the behaviors and physiological functions of these neuropeptides coordinate.

\section{EVIDENCE FOR ENDOCRINE DISRUPTION OF SOCIAL TRAITS AND CHEMICAL CONTRIBUTIONS TO PSYCHOSOCIAL SOCIAL DISORDERS}

Exploration and understanding of how EDCs may alter the organization and function of neuroendocrine systems outside of the hypothalamic-pituitary-gonadal (HPG) and thyroid axes is underdeveloped, particularly in mammals. This is perhaps surprising given the sensitivity of neuropeptide systems to

TABLE 1 | Functions attributed to AVP/OT and thus possibly vulnerable to EDCs.

\begin{tabular}{|c|c|}
\hline Oxytocin (OT) & Vasopressin (AVP) \\
\hline \multicolumn{2}{|l|}{ Neurohypophysial actions } \\
\hline$\uparrow$ Parasympathetic autonomic functions & $\begin{array}{l}\uparrow \text { Sympathetic and parasympathetic } \\
\text { regulation }\end{array}$ \\
\hline Milk letdown & $\uparrow$ Vasoconstriction \\
\hline Uterine contractions at parturition & $\uparrow$ Blood pressure \\
\hline \multicolumn{2}{|l|}{ Central actions } \\
\hline$\downarrow$ Aggression $($ ㅇ > ठ $)$ & $\uparrow$ Aggression and territorial behaviors \\
\hline $\begin{array}{l}\downarrow \text { Anxiety; } \uparrow \text { relaxation, well-being, } \\
\text { and trust }\end{array}$ & $\uparrow$ Anxiety \\
\hline$\uparrow$ Initiation of social contact & $\uparrow$ Attraction and partner selection \\
\hline$\uparrow$ Pair and social bonding & $\uparrow$ Pair and social bonding $\left({ }^{\star}>\right.$ ९) \\
\hline 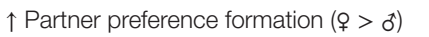 & $\uparrow$ Partner preference $(\widehat{\diamond}>$ o) \\
\hline
\end{tabular}

steroid hormones, their sexually dimorphic properties, and their diverse functional roles in the brain and peripheral organs. Growing recognition that environmental factors are likely contributing to rapidly rising rates of psychosocial disorders in which neuropeptides are thought to play a central role, including autism spectrum disorders (ASDs), has ignited greater interest in understanding how EDCs might impact targets outside of the reproductive axis. For example, while disorders of the social brain clearly have a heritable component, there is growing consensus that genetics are not fully explanatory and may possibly only account for maximally half of risk. Genetic factors contribute only an estimated $30-40 \%$ of ASD heritability, with most of that attributable to common genetic variants (11). Thus, in the vast majority of instances, ASD and other disorders of the social brain undeniably result from a complex confluence of sex specific gene vulnerabilities layered with adverse, and critically timed, environmental interactions including chemical exposures. The challenge is figuring out which chemicals, and how a "perfect storm" of genetic predispositions and environmental insults manifests as clinical disease. Elucidating the specific mechanisms by which OT and AVP signaling pathways could be vulnerable to EDCs is considered critical to identifying and understanding possible linkages between chemical exposures and psychosocial disease risk.

There are likely upwards of 90,000 chemicals in our environment today, although a full accounting has proven to be nearly impossible, even for regulators such as the US Environmental Protection Agency (EPA) who are supposedly monitoring their potential toxicity, distribution, and use (http://cen.acs.org/ articles/95/i9/chemicals-use-today.html). A subset of these is categorized as endocrine disrupting chemicals (EDCs) because of their potential to perturb endocrine systems. A consensus definition regarding what constitutes an EDC has proved elusive, and various definitions have been published each with similar but deliberately different wording (12). The precise language used for each is largely reflective of how the definition is applied and for what functional purpose it serves, particularly in a regulatory decision context. Because it was developed specifically for scientific purposes, this review will use the Endocrine Society definition, which states that an EDC is: "an exogenous chemical, or mixture of chemicals, that interferes with any aspect of hormone action" $(13,14)$. Thus, "exogenous substance" could be anthropogenic or naturally occurring [e.g., soy phytoestrogens (15)], and disruption of the organizational effects of hormones is considered most likely to result in permanent effects.

In their landmark 2006 review and call for action, environmental health scientists Philip Landrigan and Philippe Grandjean argued that industrial chemicals are undeniably contributing to the rapidly rising incidence of neurodevelopmental disorders, including ASD and attention deficit hyperactivity disorder (ADHD) (16). Although many of the chemicals identified as the most dangerous (including lead, methylmercury, and arsenic) have little to no endocrine disrupting activity, others are well known EDCs including the polychlorinated biphenols (PCBs) and many pesticides. In the subsequent decade, Landrigan and Grandjean, and numerous additional researchers have echoed and enhanced this call for greater investigation of the 
non-reproductive outcomes of EDC exposure, and emphasized the pressing need to understand how EDCs might contribute to impairments in reciprocal social engagements, repetitive/stereotypic behaviors, and other hallmark features of psychosocial and behavioral disorders $(13,17-21)$.

While it is not difficult to find broad speculation in the scientific and general literature that chemical exposures are contributing to rapidly rising rates of ASDs and ADHD, this literature is unfortunately peppered with falsely alarmist and unsubstantiated claims backed by weak or inconclusive data. Because many of these hyper-exaggerated linkages are frequently propagated by the media, there is confusion and even distrust regarding the risks EDCs pose to human health. Direct evidence linking any specific EDC to a clearly defined clinical disorder involving the social brain is sparse, and no single chemical has yet been definitively implicated $(18,21-25)$. For example, elevated prenatal androgens have been strongly associated with ASD risk for more than a decade (26-35) leading some to hypothesize that EDCs that alter androgen action may be contributory. That is clearly, however, and at the very least, only part of the story as supporting evidence in any experimental model system is extremely limited (22).

Thus, so little is known about the mechanisms by which the social brain is vulnerable to EDCs and other chemical exposures $(20,22,36)$, particularly in humans, has proven to be a formidable obstacle when trying to convince regulators and other policy makers to enact actions which reduce EDC exposure. In addition, this mechanistic information gap is a significant barrier to efficiently and proactively screening chemicals for neurodevelopmental effects, or mitigating exposures that may be contributing to psychosocial disorders. Thus, gaining clearer understanding regarding the neural underpinnings of these possible linkages is of seminal importance.

Within the EDC field, and toxicology in general, compelling phenotypes drive subsequent mechanistic inquiry. Historically, the focus of EDC research has been on the HPG axis because the first and most profound exposure-related outcomes identified were reproductive. Effects included thinning eggshells in birds, altered sex ratios in turtle clutches, distorted courtship behavior in multiple avian species, abnormal gonadal and genital morphology in alligators, and numerous instances of intersex amphibians and fish (37-39). These and other worrisome and clearly adverse reproductive phenotypes drove a multidisciplinary quest to identify the endocrine disrupting mechanisms by which such outcomes arise. Invariably, disruption of steroid hormone action was found to be causal, particularly during critical developmental windows (39-41). Similarly, as the field has matured and expanded, heightened concern over rising rates of psychosocial disorders is now driving growing interest in the impact of EDCs on non-reproductive brain regions and the hormones that coordinate social behavior, including neuropeptides.

Although no animal model can fully capture the sophisticated complexity of human social behavior, the neuroendocrine pathways coordinating numerous social traits are highly conserved $(7,42)$, including the coordinating roles of AVP and OT. Behaviors such as play, maternal care, aggressive or competitive acts, reciprocal grooming, investigation of novel conspecifics, pair bonding, and social recognition are frequently modeled in animals to explore the neural underpinnings of human social behaviors and, by extension, how they might be susceptible to chemical exposures $(39,43-49)$. Because AVP/OT and the dopaminergic pathways they feed into are heavily influenced by sex steroids across the lifespan (50-59), it is highly plausible that their sexually dimorphic ontogeny and function may be particularly vulnerable to endocrine disruption. While sparse compared to available data on reproductive endpoints, evidence from a diverse range of species has revealed that targets critical to sociality and social cognition may indeed be vulnerable to environmental exposures, including the AVP/OT system (see Table 2 for a summary).

\section{EARLY EVIDENCE FOR ENDOCRINE DISRUPTION OF AVP AND OT PATHWAYS}

That the environment, including chemical exposures, impacts the neurohypophyseal nonapeptides was first and most comprehensively described in birds (79), particularly the Japanese quail (Coturnix japonica). Seminal research dating back decades has consistently and repeatedly shown that multiple aspects of the quail VT system is vulnerable to EDCs including bisphenol A (BPA), diethylstilbestrol (DES), and high doses of the phytoestrogen genistein (GEN) $(69,70)$. In mammals and birds, the number of AVP (VT in birds) neurons and projections in the bed nucleus of the stria terminalis (BnST) and amygdala are markedly greater in males. This is one of the most consistently observed neural sex differences across taxa, and these projections are well known to coordinate sexually dimorphic social and reproductive behaviors (80). A series of studies led by Giancarlo Panzica has elegantly demonstrated the profound sensitivity of this system to embryonic manipulation by estrogens or estrogenic EDCs. Exogenous administration of estrogen, diethylstilbestrol (DES), or an aromatase inhibitor during incubation fully blocked male copulatory behavior at puberty and induced the complete sex reversal of VT-ir in the preoptic area, BnST, and lateral septum (LS) (70, 81). Reduced male copulatory behavior was also observed following embryonic exposure to high doses of the phytoestrogen genistein (GEN) (69), which is one of the most potent EDCs on nuclear estrogen receptors (ERs), particularly $\operatorname{ER} \beta(82,83)$. Demasculinization of VT-ir was induced by embryonic GEN, and $p, p^{\prime}$-DDE [a long-lived metabolite of dichlorodiphenyltrichloroethane (DDT)] (69). Other EDCs also shown to suppress male copulatory behavior following embryonic exposure, purportedly via interference with estrogen and androgen pathways, include atrazine (herbicide), methoxychlor (pesticide), and vinclozolin (fungicide) (79).

Another relatively early example of endocrine disruption in the OT/AVP system used a vole model (Microtus) (75). Within this genus, some species are spontaneously more prosocial (prairie and pine voles; Microtus ochrogaster and Microtus pinetorum, respectively) than their promiscuous relatives (montane and meadow voles; Microtus montanus and Microtus pennsylvanicus, respectively), and rats or mice. Social attachment is rare in mammals but a hallmark of human social interactions. Foundational 
TABLE 2 | EDCs shown to impact AVP/oxytocin (OT) pathways and related behaviors.

\begin{tabular}{|c|c|c|c|c|}
\hline Chemical & Category/use & Effects & $\begin{array}{l}\text { Primary mode of } \\
\text { action }\end{array}$ & Reference \\
\hline Bisphenol A (BPA) & $\begin{array}{l}\text { Stabilizer in hard plastics and } \\
\text { epoxy resins }\end{array}$ & $\begin{array}{l}\text { Altered AVP and OT neuron numbers and innervation of sexually } \\
\text { dimorphic regions associated with social and aggressive } \\
\text { behaviors in multiple species; anxiogenic in multiple species }\end{array}$ & Estrogen disruptor & $(60-66)$ \\
\hline Chlorpyrifos & Insecticide & $\begin{array}{l}\text { Altered hypothalamic AVP and OT levels (mRNA and protein); } \\
\text { sexually dimorphic impacts on social, exploratory, and anxiety- } \\
\text { related behaviors }\end{array}$ & $\begin{array}{l}\text { Acetylcholinesterase } \\
\text { inhibitor }\end{array}$ & $(67,68)$ \\
\hline $\begin{array}{l}\text { Dichlorodiphenyltrichloroethane } \\
\text { (DDT) }\end{array}$ & $\begin{array}{l}\text { Pesticide (restricted in the USA } \\
\text { but still in use globally) }\end{array}$ & Demasculinized vasotocin innervation in Japanese quail & $\begin{array}{l}\text { Estrogen and } \\
\text { androgen disruptor }\end{array}$ & (69) \\
\hline Genistein (GEN) & $\begin{array}{l}\text { Isoflavone phytoestrogen found } \\
\text { in soy and other legumes }\end{array}$ & $\begin{array}{l}\text { Altered AVP and OT neuron numbers and innervation of sexually } \\
\text { dimorphic regions associated with social and aggressive } \\
\text { behaviors in multiple species; anxiogenic in males of multiple } \\
\text { species }\end{array}$ & $\begin{array}{l}\text { Estrogen and } \\
\text { thyroid hormone } \\
\text { disruptor }\end{array}$ & $(69-74)$ \\
\hline Methoxychlor & Insecticide & $\begin{array}{l}\text { Abrogated male copulatory behavior in Japanese quail; } \\
\text { disrupted female affiliative behavior in female prairie voles }\end{array}$ & Estrogen disruptor & (75) \\
\hline $\begin{array}{l}\text { Polybrominated diphenyl ethers } \\
\text { (PBDEs) }\end{array}$ & $\begin{array}{l}\text { Fire retardants (currently being } \\
\text { phased out of use but rapidly } \\
\text { replaced with structurally } \\
\text { similarly compounds) }\end{array}$ & $\begin{array}{l}\text { Impaired AVP release from the SON in response to dehydration; } \\
\text { disruption of nitric oxide release related to AVP function in rats }\end{array}$ & $\begin{array}{l}\text { Thyroid hormone } \\
\text { disruptor }\end{array}$ & $(76-78)$ \\
\hline $\begin{array}{l}\text { Polychlorinated biphenols } \\
\text { (PCBs) }\end{array}$ & $\begin{array}{l}\text { Now banned organochlorides } \\
\text { used in many industrial } \\
\text { applications including in paints, } \\
\text { hydraulic fluids, lubricants, } \\
\text { adhesives, pesticide mixtures, } \\
\text { and sealants }\end{array}$ & $\begin{array}{l}\text { Impaired AVP release from the SON in response to dehydration } \\
\text { in rats }\end{array}$ & $\begin{array}{l}\text { Estrogen and } \\
\text { thyroid hormone } \\
\text { disruptor }\end{array}$ & $(76,77)$ \\
\hline Vinclozolin & Fungicide & Suppressed male copulatory behavior in Japanese quail & Androgen disruptor & (79) \\
\hline
\end{tabular}

research in voles has uncovered the significance of neuropeptidergic regulation of social behaviors including paternal care, pair bonding, and maternal aggression $(3,45)$. In the socially monogamous pine vole, perinatal oral exposure to approximately $2,000 \mu \mathrm{g} / \mathrm{kg}$ bw methoxychlor produced some offspring effects, but only in females (75). A non-significant trend toward increased time spent alone in the partner preference test and less aggression toward a strange male was interpreted to indicate a reduced preference for the mate and a disruption in affiliative behavior. OTR binding was unchanged in LS but reduced in the cingulate of the exposed females compared to unexposed controls. This region is thought to play a key role in stress responses and emotional processing (84). In their conclusions, the authors advocated for wider use of the vole model because "monogamous mammals share a common reproductive pattern of long-term bond. The pine vole may prove to be a new and important model for species displaying monogamy, including humans (75)." Surprisingly, no one in the EDC community heeded this call, and no work was subsequently performed in the vole model until we began our own line of investigation with BPA and prairie voles nearly a decade after this pioneering study.

Overall, the literature on EDCs and AVP/OT pathways remains small, and work has primarily focused on a small subset of high priority chemicals, most of which are known disruptors of estrogen signaling pathways. Yet, it highlights the importance of exploring alternative modes of action when thinking about neurotoxicants and EDCs. Three representative examples are discussed in depth below.

\section{BISPHENOL A (BPA)}

There is perhaps a no more notorious or thoroughly studied EDC than BPA. Present in polycarbonate plastics, the epoxy lining of canned foods, thermal paper, and other common household products, BPA is classified as a "high volume production" compound and continuous low level (resulting in mean blood levels of $4 \mathrm{ng} / \mathrm{ml}$ or lower) exposure is virtually ubiquitous and unavoidable (85). Although frequently characterized as "weakly estrogenic" BPA effects are multi-modal. For example, we have repeatedly shown that developmental exposure to doses as low as $2.5 \mu \mathrm{g} / \mathrm{kg}$ bw sex specifically alters the mRNA expression of ER $\alpha$ and ER $\beta$ in sexually dimorphic hypothalamic and limbic subnuclei in the neonatal and older rat brain (86-90). Neurobehavioral outcomes purportedly mediated via androgen receptors and epigenetic effects have also been reported (91-93). The dose defined as the "no adverse effect level" for systemic toxicity and thus the dose level below which biologically meaningful effects purportedly do not occur is $5 \mathrm{mg} / \mathrm{kg}$ bw per day. The level considered "safe" for human exposure is extrapolated from this level and is $50 \mu \mathrm{g} / \mathrm{kg}$ bw per day according to the US EPA, and $4 \mu \mathrm{g} / \mathrm{kg}$ bw per day in the European Union.

Information regarding BPA-related impacts on nonapeptide pathways is limited, but we and others have generated some evidence, in a diverse range of taxa, showing that developmental exposure to BPA alters the organization and function of AVP and OT pathways. In a study done in collaboration with Andrea Gore's laboratory, we found that Wistar rats perinatally exposed to BPA 
via drinking water [ $1 \mathrm{mg} / \mathrm{L}$; a dosing regimen that resulted in serum levels approximately equivalent to humans (94)], displayed elevated anxiety-related behaviors as juveniles (60). Consumption of a soy-rich diet, which is hormonally active and contains estrogenic phytoestrogens including GEN, ameliorated the behavioral effects to some degree. This outcome was somewhat surprising. We had predicted that BPA and soy would have additive effects because of their similar modes of action. Interactions with diet may explain some of the inconsistencies in the BPA literature regarding effects on brain and behavior $(93,95)$. Nevertheless, linkages between developmental BPA exposure and an anxiogenic phenotype have repeatedly been shown in dozens of studies using a variety of animal models and human populations (representative examples include $(62,91,93,96-100))$. Acceptance of this outcome by the risk assessment community has been tentative because the causal mechanism(s) remains unclear (94). In our Wistar rat study, exposure decreased ER $\beta$ and Mc4r expression levels in the amygdala of both sexes. These genes play crucial roles in regulating the production and release of AVP and OT in the PVN. Specifically, agonism of Mc4R in magnocellular neurons induces dendritic secretion of OT (101), an effect that is anxiolytic $(102,103)$. As a follow-up to our initial study, expression levels were subsequently examined in the PVN of the same Wistar rats using identical methodology. There was some evidence for downregulation of AVP mRNA in BPA-exposed females, but the effect did not quite reach statistical significance $(p \leq 0.07)$, and no effect on OT, AVP1aR, OTR, or Mc4R expression was observed in either sex (unpublished observations). As was observed in the amygdala, BPA produced no effects on any genes of interest in rats reared on the soy-rich diet, highlighting the significance of other environmental factors, including diet, when seeking evidence of endocrine disruption. Lack of effects on transcription does not necessarily indicate lack of effects on translation, transport, or release, and it is possible that only subpopulations of PVN neurons are susceptible, necessitating an experimental approach with great anatomical resolution to assess possible effects. In addition, AVP and OT are released via multiple mechanisms $(2,5)$, sometimes simultaneously, including volume diffusion through the extracellular space following release from large dense core vesicles, widespread circulation through the ventricular system, and targeted release into specialized extrahypothalamic regions, any or all of which might be vulnerable to EDCs.

In a separate study, we showed that that neonatal exposure to BPA ( $50 \mathrm{mg} / \mathrm{kg}$ bw or $50 \mu \mathrm{g} / \mathrm{kg}$ bw) by subcutaneous injection can alter the number of PVN OT immunolabeled cells in adulthood (in female rats) (61). Internal BPA levels were not assessed for this study, but because injection bypasses first metabolism, circulating BPA levels were undoubtedly higher than the study described above and higher than typical human levels. Exposure significantly increased OT-immunoreactive (-ir) neuron numbers, but only in the anterior PVN, a result interpreted to potentially indicate sequestration of OT and reduced release from nerve terminals. Similar outcomes were observed in a subsequent study using the prairie vole model (62). Animals were orally exposed over PNDs 18 - 14 to 5,50 , or $50,000 \mu \mathrm{g} / \mathrm{kg}$ bw and tested as juveniles or adults. Females in the highest exposure group had fewer OT-ir neurons in the posterior PVN but more AVP-ir neurons in the anterior PVN.
At the lower two doses, BPA eliminated the well-characterized sex difference in PVN TH-ir neuron numbers and reversed it at the highest dose. This effect was mirrored by similar alterations in social investigation. In this species, males are typically more inclined to interact with a novel animal than females. At the two lower doses, BPA eliminated this sex difference and at the highest dose, reversed it. Disruption of pBnST TH-ir neuron numbers also occurred at the lowest dose, but not the higher two making that outcome somewhat more difficult to interpret. These data are not in complete directional accord with our rat study, an outcome that could result from the different exposure window, doses used, or species differences in OT/AVP pathways. Ongoing studies are underway to try and resolve these differences.

A series of studies led by Emilie Rissman using C57BL/6J mice suggests that BPA-related effects on OT and AVP signaling pathways may be multi- and transgenerational. In this model, the dams (F0) are exposed to BPA during pregnancy so offspring (F1) exposure is gestational. The subsequent generation (F2) is exposed as developing germ cells in the ovaries of their embryonic F1 parents. Thus, this generation is also "directly" exposed. The F3 generation is the first generation regarded as unexposed and thus the first set of offspring in which truly transgenerational effects can be assessed (63). Mice reared on a diet delivering approximately $170 \mu \mathrm{g} / \mathrm{kg}$ bw BPA (to the dams) during gestation displayed social deficits, particularly in females, that coincided with a decrease in AVP mRNA expression levels in whole embryonic brains obtained from their ED18.5 siblings (both sexes). AVP levels were also decreased in the F4 embryos of both sexes albeit to a lesser degree $(64,65)$. Reduced OT mRNA expression was observed in the F4 males. Evidence of effects on social behavior, including juvenile social recognition and social investigation, was reported but directionally inconsistent across generations with the F1 generation showing heightened social investigation and the $\mathrm{F} 3$ generation displaying reduced responses to novel females, and the F4 mice more actively engaged with their social peers than those from an unexposed lineage (104). A subset of adult F1 and F3 mice were examined via immunohistochemistry to asses if BPA had altered sexually dimorphic AVP-ir levels in several brain regions. F1 males had fewer AVP-ir in the MePD than unexposed males, but females were unaffected. No evidence of disrupted AVP-ir levels was found for the MePD, PVN, LS or BnST (66).

Collectively, these findings support the hypothesis that BPA exposure may disrupt the organization of AVP/OT pathways arising in the PVN, thereby impacting related social behaviors. They also suggest, unsurprisingly, that specific outcomes likely differ between sex and species depending on the degree to which they are prosocial. Additional environmental factors, including diet, may modify outcomes and contribute to discordance across studies. Experiments with a greater emphasis on linking cause and effect are greatly needed to estimate the degree to which BPA may affect AVP/OT systems in humans.

\section{CHLORPYRIFOS (CPF)}

Organophosphate pesticides make up approximately $70 \%$ of all pesticides in the USA and are developmental neurotoxicants 
related to nerve agents such as Sarin and VX. Although their primary mechanism of action is inhibition of acetylcholinesterase, they can also have endocrine disrupting properties, particularly at dose levels which are more environmentally relevant and well below those which cause systemic toxicity $(16,22,105)$. CPF has been linked to ADHD and other developmental neural disorders in children, prompting the EPA to impose a ban on residential use in $2001(22,106,107)$. A complete ban was recommended in 2016 but has not been implemented. CPF will thus remain in use for golf courses, and about 50 different types of crops, including corn, soybeans, row crops (such as broccoli), and fruit trees. Work in mice and rats has repeatedly shown that developmental exposure results in long-lasting (and sometimes sex specific) effects on emotional functions, activity, learning, serotonergic and dopaminergic transmission, neuronal differentiation, and synaptogenesis (108). Collectively, these effects implicate peptidergic pathways as a possible target for endocrine disruption.

Data in support of CPF as a peptidergic disruptor are sparse but suggestive of sex-specific vulnerability. In CD1 mice, preand/or postnatal exposure to CPF resulted in a dose-dependent decrease in hypothalamic AVP at 5 months of age concomitantly with increased OT (67). This outcome was more pronounced in males than females and following pre-, rather than post-, natal exposure. The same group subsequently reported effects on OT and AVP mRNA expression in the amygdala as well as the hypothalamus (68). Notably, ER $\beta$ was also found to be upregulated in the male hypothalamus. In both studies CPF-exposed mice displayed altered social and exploratory behaviors, with the specific outcomes differing by sex. Collectively, these data are consistent with a robust body of evidence showing that CPF is a developmental neurotoxin and endocrine disruptor, and a likely environmental contributor to ASD, ADHD, and other behavioral disorders. Additional work in other species is needed to provide resolution regarding the degree to which CPF can interfere with AVP and OT signaling pathways.

\section{PHYTOESTROGENS}

Not all EDCs are anthropogenic. Soy and other legumes contain isoflavone phytoestrogens, which are used to aid in the recruitment of nitrogen-fixing bacteria but are also well-characterized xenoestrogens $(83,109,110)$. GEN, for example, is found in soybased and soy-supplemented foods, including soy infant formula, and can be purchased as a dietary supplement. Evidence of the endocrine disrupting properties of GEN dates back decades, and soy is so well recognized as a hormonally active food, that it is frequently advertised and promoted as such $(15,111-115)$. As with BPA and other manufactured EDCs, the majority of GEN studies have focused on reproductive endpoints (although with the distinctive difference that, historically, most studies presume possible outcomes will be "beneficial" because soy is "natural" while BPA is not), but there are some data showing endocrine disruption of AVP-related pathways and systems, including behaviors (112).

Although initially thought to be anxiolytic (116), long-term consumption of soy-rich diets has been shown to enhance aggression in male cynomolgus monkeys (117) and Syrian hamsters
(72), the latter of which also had lower AVP1A expression in the LS but higher AVP1A expression in lateral hypothalamus. My lab has also shown that two dietary isoflavone supplements produced anxiolytic elevated plus maze behavior in proestrus female rats, but anxiogenic responses in gonadally intact males (118). Similarly, male rats maintained on a diet containing $150 \mu \mathrm{g} / \mathrm{g} \mathrm{GEN}$ and daidzein displayed increased anxiety and elevated stressinduced plasma AVP and corticosterone levels (71). Elevated hypothalamic AVP content (measured by ELISA) has also been reported in rats maintained on a diet containing 1,250 ppm GEN (73). Sexually dimorphic AVP-ir in the rodent brain can also be altered by early-life exposure to GEN, including at doses akin to the levels found in soy infant formula. For example, in CD1 mice, oral intake of $50 \mu \mathrm{g} / \mathrm{kg}$ GEN in the first week of life slightly, but significantly increased AVP-ir in the female BnST but did not impact the sexually dimorphic AVP innervation of the LS (74). Notably, the sexually dimorphic density of AVP-ir neurons in the medial parvicellular part of the PVN (PaMP) was eliminated by postnatal GEN, with higher numbers in females and lower numbers in males.

Dietary consumption of soy is globally increasing, meriting greater understanding of its endocrine disrupting properties, particularly in infants and young children. Although sex-specific isoflavone-related effects on the rodent AVP/OT system have been sporadically shown by multiple laboratories, including my own, work in this area remains limited and incomplete. In some regards, this is because work on "natural" EDCs is notoriously difficult to obtain funding for. There is also a problem of perception. While concerns about BPA, fire retardants, and other manufactured EDCs remains high, phytoestrogens are some of the most potent xenoestrogens humans regularly are exposed to. Arguably, they are one of the most significant but underappreciated EDCs of concern.

\section{ENDOCRINE DISRUPTION OF AVP/OT PATHWAYS: A ROLE FOR ERs}

How chemicals interact with and perturb AVP/OT pathways are undoubtedly multi-modal, but action on ERs, and disruption of ER expression, is likely a primary mechanism by which BPA, GEN, and other EDCs influence AVP/OT pathways. That non-classical EDCs like CPF can have disruptive effects on AVP/ OT action, hint at alternative modes of action but most work to date has focused on estrogen-disrupting compounds because the organization and function of AVP/OT signaling pathways are exquisitely sensitive to steroid hormones. We have repeatedly shown that developmental BPA exposure can perturb ER $\alpha$ and $\operatorname{ER} \beta$ gene expression throughout the rat hypothalamus and components of the mesolimbic dopamine system, including the PVN and BnST (86-90), across the lifespan. Moreover, in the transgenerational mouse model, one of the most striking findings was disrupted ER $\alpha$-ir in the F3 females from the BPA-exposed lineage, with higher levels in the AVPV and lower levels in the BnST (66). The phytoestrogen coumestrol (found in clover and other pasture legumes) and GEN upregulate ER $\beta$ mRNA expression in the PVN, an effect opposite to that of $17 \beta$-estradiol 
$(119,120)$. If and how these neural effects translate to adverse behavioral phenotypes remains to be established.

How estrogens and androgens contribute to the sexual differentiation and function of the AVP/OT system are sex and species dependent and associated with functional differences in prosociality $(121,122)$. Manipulation of OT/AVP levels via direct exposures to exogenous hormones, agonists, or alteration of the social environment can significantly modify the number of OT, AVP, and TH neurons in the PVN, thereby resulting in anxiety-like behavior and alterations of prototypical male and female sociosexual behavior (123-127). Similarly, neonatal manipulation of estradiol or testosterone alters prairie vole affiliative behaviors later in life, and estradiol administration during adulthood alters estrus and locomotor activity $(57,128,129)$. Males gonadectomized on the day of birth, for example, fail to form a pair bond after AVP administration (52).

Pathways coordinating social recognition are well known to be regulated by estrogen, with both $\operatorname{ER} \alpha$ and $\operatorname{ER} \beta$ knockout mice showing social impairments $(130,131)$, and ER $\beta$ knockout females failing to generate OT or AVP mRNA expression in response to exogenous estrogen administration (132, 133). Although the functional role of limbic ER $\beta$ remains ambiguous, ER $\beta$ in the PVN and associated structures, including the BnST, plays a fundamental role in mediating motivational and anxietyrelated behaviors (134-136). ER $\beta$ has also been identified as one component of a "four-gene micronet" regulating social recognition $(7,131)$ via the PVN, amygdala, and olfactory system. By this model, estradiol simultaneously acts through ER $\beta$ in the PVN to increase OT, and ER $\alpha$ in the amygdala to increase OTR expression. This view is consistent with the observation that the density of ER $\alpha$ markedly differs across prosocial and asocial species and is directly related to the degree to which individuals and species are prosocial $(3,137,138)$. Conceptualizing and testing endocrine disruption of ER-sensitive AVP pathways as a system, such as this micronet, while simultaneously accounting for species and sex differences, would further holistic understanding of how EDCs affect non-reproductive behaviors.

Finally, a subpopulation of parvocellular PVN OT and AVP neurons, along with $\mathrm{ER} \beta$ and coordinating input from the BnST, is thought to be involved in the stress response $(135,139,140)$ supporting the possibility that EDCs may influence the hypothalamic-pituitary-adrenal axis. Surprisingly, this is a neglected area of EDC research. Given the comparatively higher promiscuity of $\operatorname{ER} \beta$ (relative to $E R \alpha$ ) for ligands including multiple phytoestrogens including GEN (82), and even the androgen metabolite $5 \alpha$-androstane- $3 \beta, 17 \beta$-diol ( $3 \beta$-diol) (141), this is a strikingly understudied but likely avenue for endocrine disruption.

\section{AVP IMPACTS-BEYOND BRAIN AND BEHAVIOR}

In both rats and prairie voles, we have shown that BPA alters only specific subpopulations of OT and AVP neurons. Although we surmised that the populations of OT-ir and AVP-ir neurons impacted by BPA are primarily parvocellular, the possibility that BPA alters the density and function of magnocellular neurons could not be ruled out. This would suggest an avenue for homeostatic disruptions including cardiovascular effects and hypertension associated with BPA and, by extension, other EDCs (142, 143). Intriguingly, in humans, BPA exposure has been tentatively linked with cardiovascular disease and hypertension, but the causal mechanisms remain to be characterized (144).

Long before its role in social behavior was identified, AVP was termed the "antidiuretic hormone." Magnocellular AVP neurons in the PVN and SON release AVP both centrally and systemically in response to dehydration, hemorrhage, and stress and are known to be one of the primary physiological regulators of water-electrolyte balance (145). These AVP neurons receive osmosensitive inputs from the organum vasculosum lamina terminalis via glutamatergic synapses and are modulated by nitric oxide (NO) signaling pathways (146-148). Work using adult male rats and SON tissue punches has yielded evidence that the PCB mixture Aroclor 1254 and the structurally related polybrominated flame retardants [polybrominated diphenyl ethers (PBDEs)], including the pentabrominated mixture DE-71, significantly reduced AVP release from the SON in response to dehydration $(76,77)$. Subsequent work revealed that perinatal oral exposure to 1.7 or $30.6 \mathrm{mg} / \mathrm{kg} /$ day resulted in elevated systolic blood pressure responses at $3 \mathrm{~h}$ post-hyperosmotic challenge, an effect the authors interpreted as possibly attributable to decreased plasma AVP levels (78). A single paper also suggests that longterm exposure to chlorobenzenes (solvents) may also disrupt neurohypophysial AVP and OT release (149). Complementary work by multiple research teams has identified NO signaling as a potent target of many EDCs including PBDEs, PCBs, and other organohalogens (representative examples include $(74,150,151)$ ) suggesting another possible route by which EDCs could impact AVP function. Concomitant work focused on the parvocellular aspects of AVP signaling has also found evidence of NO endocrine disruption by GEN, BPA, and other EDCs $(39,74,151)$.

\section{SUMMARY AND CONCLUSION}

Although available data are sparse there is compounding evidence that EDCs can alter the ontogeny and function of AVP and OT signaling pathways critical to social behavior and, possibly, osmotic balance and other peripheral functions. Rising rates of behavioral, hypertensive, and other disorders for which AVP are known to play a coordinating role suggest a causal role for environmental factors, including chemical exposures, but which specific ones remains elusive. The complex chemical landscape we all face and inevitably invades us makes it challenging to identify the individual or subset of compounds that pose the greatest health risks to this and subsequent generations. Data from a myriad of species from birds to mammals, however, suggest that EDCs that interfere with estrogen signaling (including BPA, GEN, PBDEs, and PCBs) are plausible disruptors of AVP/OT pathways. Compared to what is known about how these EDCs alter the sex specific organization and function of reproductive neuroendocrine pathways, investigation of nonapeptide disruption is in its relative infancy, but a topic of heightening interest and exploration. Moreover, only a handful of compounds have been tested for AVP-related outcomes at all. 
Going forward, there is a compelling need to understand and develop effective screening methods for EDC activity, particularly on non-steroid hormone targets, to get a better handle on what possible consequences this chemical class may pose to human health. As this paper went to press the EPA's endocrine disruptor screening program (EDSP), an effort that took more than two decades to construct, and only recently reached the capacity to effectively identify any chemical as a purported EDC, was slated for elimination. If cut, this would leave absolutely no mechanism for screening any extant or pre-market chemicals for any EDC activity of any kind. The assays within the EDSP are reasonably effective at targeting sex steroid hormone disruptors but ineffective at identifying non-steroidal endocrine disrupting activity including OT and AVP disruption (152) leaving a desperate need for improvement. Within the USA there is absolutely no federal-level mechanism in place to evaluate where EDCs are found, let alone regulate their use in common items such as cosmetics, personal care products, food containers or durable goods. Consequently, daily exposure is virtually silent and unceasingly increasing (12). Moreover, there is an ever-churning conveyer belt of worrying chemical replacements such that when EDCs, such as the PBDEs, DDT, and BPA, are finally phased out, they are rapidly replaced by structurally similar compounds. In this regard, there is a compelling need for ongoing inquiry regarding EDC activity, particularly on non-traditional targets such as AVP systems.

Future work focusing on richly estrogen sensitive limbic populations known to confer individual, sex and species differences in prosocial traits, especially the BnST, is critically needed

\section{REFERENCES}

1. Caldwell HK, Albers HE. Oxytocin, vasopressin, and the motivational forces that drive social behaviors. Curr Top Behav Neurosci (2016) 27:51-103. doi:10.1007/7854_2015_390

2. Ross HE, Young LJ. Oxytocin and the neural mechanisms regulating social cognition and affiliative behavior. Front Neuroendocrinol (2009) 30:534-47. doi:10.1016/j.yfrne.2009.05.004

3. Young KA, Gobrogge KL, Liu Y, Wang Z. The neurobiology of pair bonding: insights from a socially monogamous rodent. Front Neuroendocrinol (2011) 32:53-69. doi:10.1016/j.yfrne.2010.07.006

4. Rood BD, De Vries GJ. Vasopressin innervation of the mouse (Mus musculus) brain and spinal cord. J Comp Neurol (2011) 519:2434-74. doi:10.1002/ cne. 22635

5. Johnson ZV, Young LJ. Oxytocin and vasopressin neural networks: implications for social behavioral diversity and translational neuroscience. Neurosci Biobehav Rev (2017) 76:87-98. doi:10.1016/j.neubiorev.2017.01.034

6. Kelly AM, Goodson JL. Social functions of individual vasopressin-oxytocin cell groups in vertebrates: what do we really know? Front Neuroendocrinol (2014) 35:512-29. doi:10.1016/j.yfrne.2014.04.005

7. Albers HE. Species, sex and individual differences in the vasotocin/vasopressin system: relationship to neurochemical signaling in the social behavior neural network. Front Neuroendocrinol (2015) 36:49-71. doi:10.1016/j.yfrne. 2014.07.001

8. Neumann ID, Landgraf R. Balance of brain oxytocin and vasopressin: implications for anxiety, depression, and social behaviors. Trends Neurosci (2012) 35:649-59. doi:10.1016/j.tins.2012.08.004

9. Spetter MS, Hallschmid M. Current findings on the role of oxytocin in the regulation of food intake. Physiol Behav (2017) 176:31-9. doi:10.1016/j. physbeh.2017.03.007

10. Fuxe K, Borroto-Escuela DO, Romero-Fernandez W, Ciruela F, Manger P, Leo $\mathrm{G}$, et al. On the role of volume transmission and receptor-receptor to better understand how AVP/OT signaling pathways and, consequently, social behaviors might be vulnerable to endocrine disruption. Much EDC work, particularly on social and other non-reproductive behaviors, remains largely descriptive with limited understanding of causal relationships. Elucidating specific mechanisms of endocrine disruption is essential for establishing causality between exposure and adverse behavioral outcomes. Maximizing the probability of success will hinge on the selection of the most appropriate animal model for the specific question being addressed, and the translational value of the outcome for human neurophysiology. Neuroendocrinologists familiar with a wide range of taxa are well poised for critical discovery because classical toxicology still overly relies on dated testing strategies and traditional rat models. Incredibly, toxicology is still struggling to incorporate transgenic animals and other more modern approaches now considered basic tools of neuroscience (153, 154 ), leaving vast opportunity for the neuroendocrine community to make critical discoveries toward the goal of uncovering the chemical contributions to social disorders and other debilitating conditions such as cardiovascular disease and hypertension.

\section{AUTHOR CONTRIBUTIONS}

The sole author completed this manuscript independently.

\section{FUNDING}

This work was supported by NIEHS grants P30ES025128 and R21ES021233.

interactions in social behaviour: focus on central catecholamine and oxytocin neurons. Brain Res (2012) 1476:119-31. doi:10.1016/j.brainres. 2012.01.062

11. Sandin S, Lichtenstein P, Kuja-Halkola R, Larsson H, Hultman CM, Reichenberg A. The familial risk of autism. JAMA (2014) 311:1770-7. doi:10.1001/jama.2014.4144

12. Patisaul HB, Belcher SM. Endocrine Disruptors, Brain, and Behavior. New York: Oxford University Press (2017).

13. Gore AC, Chappell VA, Fenton SE, Flaws JA, Nadal A, Prins GS, et al. EDC-2: the endocrine society's second scientific statement on endocrine-disrupting chemicals. Endocr Rev (2015) 36:E1-150. doi:10.1210/er.2015-1010

14. Diamanti-Kandarakis E, Bourguignon JP, Giudice LC, Hauser R, Prins GS, Soto AM, et al. Endocrine-disrupting chemicals: an Endocrine Society scientific statement. Endocr Rev (2009) 30:293-342. doi:10.1210/er.2009-0002

15. Patisaul HB, Jefferson W. The pros and cons of phytoestrogens. Front Neuroendocrinol (2010) 31:400-19. doi:10.1016/j.yfrne.2010.03.003

16. Grandjean P, Landrigan PJ. Developmental neurotoxicity of industrial chemicals. Lancet (2006) 368:2167-78. doi:10.1016/S0140-6736(06)69665-7

17. Newschaffer CJ, Croen LA, Daniels J, Giarelli E, Grether JK, Levy SE, et al. The epidemiology of autism spectrum disorders. Annu Rev Public Health (2007) 28:235-58. doi:10.1146/annurev.publhealth.28.021406.144007

18. Landrigan P, Lambertini L, Birnbaum L. A research strategy to discover the environmental causes of autism and neurodevelopmental disabilities. Environ Health Perspect (2012) 120:a258-60. doi:10.1289/ehp.1104285

19. Gore AC, Martien KM, Gagnidze K, Pfaff D. Implications of prenatal steroid perturbations for neurodevelopment, behavior, and autism. Endocr Rev (2014) 35:961-91. doi:10.1210/er.2013-1122

20. Sealey LA, Hughes BW, Sriskanda AN, Guest JR, Gibson AD, JohnsonWilliams L, et al. Environmental factors in the development of autism spectrum disorders. Environ Int (2016) 88:288-98. doi:10.1016/j.envint.2015.12.021

21. Kalkbrenner AE, Schmidt RJ, Penlesky AC. Environmental chemical exposures and autism spectrum disorders: a review of the epidemiological evidence. 
Curr Probl Pediatr Adolesc Health Care (2014) 44:277-318. doi:10.1016/j. cppeds.2014.06.001

22. Grandjean P, Landrigan PJ. Neurobehavioural effects of developmental toxicity. Lancet Neurol (2014) 13:330-8. doi:10.1016/S1474-4422(13)70278-3

23. Fujiwara T, Morisaki N, Honda Y, Sampei M, Tani Y. Chemicals, nutrition, and autism spectrum disorder: a mini-review. Front Neurosci (2016) 10:174. doi:10.3389/fnins.2016.00174

24. Aguiar A, Eubig PA, Schantz SL. Attention deficit/hyperactivity disorder: a focused overview for children's environmental health researchers. Environ Health Perspect (2010) 118:1646-53. doi:10.1289/ehp.1002326

25. Eubig PA, Aguiar A, Schantz SL. Lead and PCBs as risk factors for attention deficit/hyperactivity disorder. Environ Health Perspect (2010) 118:1654-67. doi:10.1289/ehp.0901852

26. Baron-Cohen S, Knickmeyer RC, Belmonte MK. Sex differences in the brain: implications for explaining autism. Science (2005) 310:819-23. doi:10.1126/ science. 1115455

27. Alexander GM. Postnatal testosterone concentrations and male social development. Front Endocrinol (2014) 5:15. doi:10.3389/fendo.2014.00015

28. Auyeung B, Taylor K, Hackett G, Baron-Cohen S. Foetal testosterone and autistic traits in 18 to 24-month-old children. Mol Autism (2010) 1:11. doi:10.1186/2040-2392-1-11

29. Auyeung B, Baron-Cohen S, Ashwin E, Knickmeyer R, Taylor K, Hackett G. Fetal testosterone and autistic traits. Br J Psychol (2009) 100:1-22. doi:10.134 8/000712608X311731

30. Johnson MH, Griffin R, Csibra G, Halit H, Farroni T, de Haan M, et al. The emergence of the social brain network: evidence from typical and atypical development. Dev Psychopathol (2005) 17:599-619. doi:10.1017/ S0954579405050297

31. Baron-Cohen S. Testing the extreme male brain (EMB) theory of autism: let the data speak for themselves. Cogn Neuropsychiatry (2005) 10:77-81. doi:10.1080/13546800344000336

32. James WH. An update on the hypothesis that one cause of autism is high intrauterine levels of testosterone of maternal origin. J Theor Biol (2014) 355:33-9. doi:10.1016/j.jtbi.2014.03.036

33. Knickmeyer RC, Wheelwright S, Baron-Cohen SB. Sex-typical play: masculinization/defeminization in girls with an autism spectrum condition. J Autism Dev Disord (2008) 38:1028-35. doi:10.1007/s10803-007-0475-0

34. Palomba S, Marotta R, Di Cello A, Russo T, Falbo A, Orio F, et al. Pervasive developmental disorders in children of hyperandrogenic women with polycystic ovary syndrome: a longitudinal case-control study. Clin Endocrinol (Oxf) (2012) 77:898-904. doi:10.1111/j.1365-2265.2012.04443.x

35. Pohl A, Cassidy S, Auyeung B, Baron-Cohen S. Uncovering steroidopathy in women with autism: a latent class analysis. Mol Autism (2014) 5:27. doi:10.1186/2040-2392-5-27

36. Rebuli ME, Patisaul HB. Assessment of sex specific endocrine disrupting effects in the prenatal and pre-pubertal rodent brain. J Steroid Biochem Mol Biol (2015) 160:148-59. doi:10.1016/j.jsbmb.2015.08.021

37. Guillette LJ Jr, Gunderson MP. Alterations in development of reproductive and endocrine systems of wildlife populations exposed to endocrinedisrupting contaminants. Reproduction (2001) 122:857-64. doi:10.1530/ rep. 0.1220857

38. Hotchkiss AK, Rider CV, Blystone CR, Wilson VS, Hartig PC, Ankley GT, et al. Fifteen years after "Wingspread" - environmental endocrine disrupters and human and wildlife health: where we are today and where we need to go. Toxicol Sci (2008) 105:235-59. doi:10.1093/toxsci/kfn030

39. Frye CA, Bo E, Calamandrei G, Calza L, Dessi-Fulgheri F, Fernandez M, et al. Endocrine disrupters: a review of some sources, effects, and mechanisms of actions on behaviour and neuroendocrine systems. J Neuroendocrinol (2012) 24:144-59. doi:10.1111/j.1365-2826.2011.02229.x

40. Crain DA, Janssen SJ, Edwards TM, Heindel J, Ho SM, Hunt P, et al. Female reproductive disorders: the roles of endocrine-disrupting compounds and developmental timing. Fertil Steril (2008) 90:911-40. doi:10.1016/j. fertnstert.2008.08.067

41. Toppari J, Larsen JC, Christiansen P, Giwercman A, Grandjean P, Guillette LJ Jr, et al. Male reproductive health and environmental xenoestrogens. Environ Health Perspect (1996) 104:741-803. doi:10.2307/3432709

42. Adkins-Regan E. Neuroendocrinology of social behavior. ILAR J (2009) 50:5-14. doi:10.1093/ilar.50.1.5
43. Patisaul HB, Adewale HB. Long-term effects of environmental endocrine disruptors on reproductive physiology and behavior. Front Behav Neurosci (2009) 3:10. doi:10.3389/neuro.08.010.2009

44. Brosnan SF, Freeman C, De Waal FB. Partner's behavior, not reward distribution, determines success in an unequal cooperative task in capuchin monkeys. Am J Primatol (2006) 68:713-24. doi:10.1002/ajp.20261

45. McGraw LA, Young LJ. The prairie vole: an emerging model organism for understanding the social brain. Trends Neurosci (2010) 33:103-9. doi:10.1016/j. tins.2009.11.006

46. Decety J, Svetlova M. Putting together phylogenetic and ontogenetic perspectives on empathy. Dev Cogn Neurosci (2012) 2:1-24. doi:10.1016/j. dcn.2011.05.003

47. MacLean EL, Matthews LJ, Hare BA, Nunn CL, Anderson RC, Aureli F, et al. How does cognition evolve? Phylogenetic comparative psychology. Anim Cogn (2012) 15:223-38. doi:10.1007/s10071-011-0448-8

48. Watson KK, Platt ML. Of mice and monkeys: using non-human primate models to bridge mouse- and human-based investigations of autism spectrum disorders. J Neurodev Disord (2012) 4:21. doi:10.1186/18661955-4-21

49. Chang SW, Barter JW, Ebitz RB, Watson KK, Platt ML. Inhaled oxytocin amplifies both vicarious reinforcement and self reinforcement in rhesus macaques (Macaca mulatta). Proc Natl Acad Sci U S A (2012) 109:959-64. doi:10.1073/pnas.1114621109

50. Simerly RB, Swanson LW, Handa RJ, Gorski RA. Influence of perinatal androgen on the sexually dimorphic distribution of tyrosine hydroxylaseimmunoreactive cells and fibers in the anteroventral periventricular nucleus of the rat. Neuroendocrinology (1985) 40:501-10. doi:10.1159/000124122

51. Cushing BS, Kramer KM. Mechanisms underlying epigenetic effects of early social experience: the role of neuropeptides and steroids. Neurosci Biobehav $\operatorname{Rev}(2005)$ 29:1089-105. doi:10.1016/j.neubiorev.2005.04.001

52. Cushing BS, Okorie U, Young LJ. The effects of neonatal castration on the subsequent behavioural response to centrally administered arginine vasopressin and the expression of V1a receptors in adult male prairie voles. J Neuroendocrinol (2003) 15:1021-6. doi:10.1046/j.1365-2826.2003.01097.x

53. Lonstein JS, De Vries GJ. Sex differences in the parental behavior of rodents. Neurosci Biobehav Rev (2000) 24:669-86. doi:10.1016/S0149-7634(00)00036-1

54. Kabelik D, Schrock SE, Ayres LC, Goodson JL. Estrogenic regulation of dopaminergic neurons in the opportunistically breeding zebra finch. Gen Comp Endocrinol (2011) 173:96-104. doi:10.1016/j.ygcen.2011.04.026

55. Cavanaugh BL, Lonstein JS. Androgenic and oestrogenic influences on tyrosine hydroxylase-immunoreactive cells of the prairie vole medial amygdala and bed nucleus of the stria terminalis. J Neuroendocrinol (2010) 22:217-25. doi:10.1111/j.1365-2826.2010.01958.x

56. Cushing BS, Perry A, Musatov S, Ogawa S, Papademetriou E. Estrogen receptors in the medial amygdala inhibit the expression of male prosocial behavior. J Neurosci (2008) 28:10399-403. doi:10.1523/JNEUROSCI. 1928-08.2008

57. Kramer KM, Perry AN, Golbin D, Cushing BS. Sex steroids are necessary in the second postnatal week for the expression of male alloparental behavior in prairie voles (Microtus ochragaster). Behav Neurosci (2009) 123:958-63. doi:10.1037/a0016927

58. Perry AN, Sue Carter C, Cushing BS. Effects of postnatal estrogen manipulations on juvenile alloparental behavior. Horm Behav (2015) 75:11-7. doi:10.1016/j.yhbeh.2015.07.019

59. Ploskonka SD, Eaton JL, Carr MS, Schmidt JV, Cushing BS. Developmental expression of estrogen receptor beta in the brain of prairie voles (Microtus ochrogaster). Dev Psychobiol (2015) 58(2):223-30. doi:10.1002/dev.21367

60. Patisaul HB, Sullivan AW, Radford ME, Walker DM, Adewale HB, Winnik B, et al. Anxiogenic effects of developmental bisphenol A exposure are associated with gene expression changes in the juvenile rat amygdala and mitigated by soy. PLoS One (2012) 7:e43890. doi:10.1371/journal.pone.0043890

61. Adewale HB, Todd KL, Mickens JA, Patisaul HB. The impact of neonatal bisphenol-A exposure on sexually dimorphic hypothalamic nuclei in the female rat. Neurotoxicology (2011) 32:38-49. doi:10.1016/j.neuro.2010.07.008

62. Sullivan AW, Beach EC, Stetzik LA, Perry A, D’Addezio AS, Cushing BS, et al. A novel model for neuroendocrine toxicology: neurobehavioral effects of BPA exposure in a prosocial species, the prairie vole (Microtus ochrogaster). Endocrinology (2014) 155:3867-81. doi:10.1210/en.2014-1379 
63. Rissman EF, Adli M. Minireview: transgenerational epigenetic inheritance: focus on endocrine disrupting compounds. Endocrinology (2014) 155: 2770-80. doi:10.1210/en.2014-1123

64. Wolstenholme JT, Taylor JA, Shetty SR, Edwards M, Connelly JJ, Rissman EF. Gestational exposure to low dose bisphenol A alters social behavior in juvenile mice. PLoS One (2011) 6:e25448. doi:10.1371/journal.pone.0025448

65. Wolstenholme JT, Edwards M, Shetty SR, Gatewood JD, Taylor JA, Rissman EF, et al. Gestational exposure to bisphenol a produces transgenerational changes in behaviors and gene expression. Endocrinology (2012) 153:3828-38. doi:10.1210/en.2012-1195

66. Goldsby JA, Wolstenholme JT, Rissman EF. Multi- and transgenerational consequences of bisphenol A on sexually dimorphic cell populations in mouse brain. Endocrinology (2017) 158:21-30. doi:10.1210/en.2016-1188

67. Tait S, Ricceri L, Venerosi A, Maranghi F, Mantovani A, Calamandrei G. Longterm effects on hypothalamic neuropeptides after developmental exposure to chlorpyrifos in mice. Environ Health Perspect (2009) 117:112-6. doi:10.1289/ ehp. 11696

68. Venerosi A, Tait S, Stecca L, Chiarotti F, De Felice A, Cometa MF, et al. Effects of maternal chlorpyrifos diet on social investigation and brain neuroendocrine markers in the offspring - a mouse study. Environ Health (2015) 14:32. doi:10.1186/s12940-015-0019-6

69. Viglietti-Panzica C, Mura E, Panzica G. Effects of early embryonic exposure to genistein on male copulatory behavior and vasotocin system of Japanese quail. Horm Behav (2007) 51:355-63. doi:10.1016/j.yhbeh.2006.12.003

70. Panzica G, Mura E, Pessatti M, Viglietti-Panzica C. Early embryonic administration of xenoestrogens alters vasotocin system and male sexual behavior of the Japanese quail. Domest Anim Endocrinol (2005) 29:436-45. doi:10.1016/j. domaniend.2005.02.010

71. Hartley DE, Edwards JE, Spiller CE, Alom N, Tucci S, Seth P, et al. The soya isoflavone content of rat diet can increase anxiety and stress hormone release in the male rat. Psychopharmacology (Berl) (2003) 167:46-53. doi:10.1007/ s00213-002-1369-7

72. Moore TO, Karom M, O'Farrell L. The neurobehavioral effects of phytoestrogens in male Syrian hamsters. Brain Res (2004) 1016:102-10. doi:10.1016/j. brainres.2004.04.073

73. Scallet AC, Wofford M, Meredith JC, Allaben WT, Ferguson SA. Dietary exposure to genistein increases vasopressin but does not alter beta-endorphin in the rat hypothalamus. Toxicol Sci (2003) 72:296-300. doi:10.1093/toxsci/ kfg029

74. Ponti G, Rodriguez-Gomez A, Farinetti A, Marraudino M, Filice F, Foglio B, et al. Early postnatal genistein administration permanently affects nitrergic and vasopressinergic systems in a sex-specific way. Neuroscience (2017) 346:203-15. doi:10.1016/j.neuroscience.2017.01.024

75. Engell MD, Godwin J, Young LJ, Vandenbergh JG. Perinatal exposure to endocrine disrupting compounds alters behavior and brain in the female pine vole. Neurotoxicol Teratol (2006) 28:103-10. doi:10.1016/j.ntt.2005.10.002

76. Coburn CG, Gillard ER, Curras-Collazo MC. Dietary exposure to aroclor 1254 alters central and peripheral vasopressin release in response to dehydration in the rat. Toxicol Sci (2005) 84:149-56. doi:10.1093/toxsci/kfi046

77. Coburn CG, Curras-Collazo MC, Kodavanti PR. Polybrominated diphenyl ethers and ortho-substituted polychlorinated biphenyls as neuroendocrine disruptors of vasopressin release: effects during physiological activation in vitro and structure-activity relationships. Toxicol Sci (2007) 98:178-86. doi:10.1093/toxsci/kfm086

78. Shah A, Coburn CG, Watson-Siriboe A, Whitley R, Shahidzadeh A, Gillard ER, et al. Altered cardiovascular reactivity and osmoregulation during hyperosmotic stress in adult rats developmentally exposed to polybrominated diphenyl ethers (PBDEs). Toxicol Appl Pharmacol (2011) 256:103-13. doi:10.1016/ j.taap.2011.07.014

79. Ottinger MA, Lavoie E, Thompson N, Barton A, Whitehouse K, Barton M, et al. Neuroendocrine and behavioral effects of embryonic exposure to endocrine disrupting chemicals in birds. Brain Res Rev (2008) 57:376-85. doi:10.1016/j. brainresrev.2007.08.011

80. De Vries GJ, Panzica GC. Sexual differentiation of central vasopressin and vasotocin systems in vertebrates: different mechanisms, similar endpoints. Neuroscience (2006) 138:947-55. doi:10.1016/j.neuroscience.2005.07.050

81. Panzica GC, Castagna C, Viglietti-Panzica C, Russo C, Tlemcani O, Balthazart J. Organizational effects of estrogens on brain vasotocin and sexual behavior in quail. J Neurobiol (1998) 37:684-99. doi:10.1002/ (SICI)1097-4695(199812)37:4<684::AID-NEU15>3.0.CO;2-U

82. Kuiper GG, Lemmen JG, Carlsson B, Corton JC, Safe SH, van der Saag PT, et al. Interaction of estrogenic chemicals and phytoestrogens with estrogen receptor beta. Endocrinology (1998) 139:4252-63. doi:10.1210/endo. 139.10.6216

83. Kuiper GGJM, Carlsson B, Grandien K, Enmark E, Häggblad J, Hilsson S, et al. Comparison of the ligand binding specificity and transcript tissue distribution of estrogen receptors $\alpha$ and $\beta$. Endocrinology (1997) 138:863-70. doi:10.1210/ endo.138.3.4979

84. Singewald GM, Rjabokon A, Singewald N, Ebner K. The modulatory role of the lateral septum on neuroendocrine and behavioral stress responses. Neuropsychopharmacology (2011) 36:793-804. doi:10.1038/npp.2010.213

85. Bergman A, Heindel JJ, Jobling S, Kidd KA, Zoeller RT, editors. WHO/UNEP, State of the Science of Endocrine Disrupting Chemicals - 2012. United National Environment Programme World Health Organization (2012). 296 p.

86. Cao J, Rebuli ME, Rogers J, Todd KL, Leyrer SM, Ferguson SA, et al. Prenatal bisphenol A exposure alters sex-specific estrogen receptor expression in the neonatal rat hypothalamus and amygdala. Toxicol Sci (2013) 133:157-73. doi:10.1093/toxsci/kft035

87. Rebuli ME, Cao J, Sluzas E, Delclos KB, Camacho L, Lewis SM, et al. Investigation of the effects of subchronic low dose oral exposure to bisphenol A (BPA) and ethinyl estradiol (EE) on estrogen receptor expression in the juvenile and adult female rat hypothalamus. Toxicol Sci (2014) 140(1):190-203. doi:10.1093/toxsci/kfu074

88. Arambula SE, Belcher SM, Planchart A, Turner SD, Patisaul HB. Impact of low dose oral exposure to bisphenol A (BPA) on the neonatal rat hypothalamic and hippocampal transcriptome: a clarity-BPA consortium study. Endocrinology (2016) 157:3856-72. doi:10.1210/en.2016-1339

89. Cao J, Joyner L, Mickens JA, Leyrer SM, Patisaul HB. Sex-specific Esr2 mRNA expression in the rat hypothalamus and amygdala is altered by neonatal bisphenol A exposure. Reproduction (2014) 147:537-54. doi:10.1530/ REP-13-0501

90. Cao J, Mickens JA, McCaffrey KA, Leyrer SM, Patisaul HB. Neonatal bisphenol A exposure alters sexually dimorphic gene expression in the postnatal rat hypothalamus. Neurotoxicology (2012) 33:23-36. doi:10.1016/j. neuro.2011.11.002

91. Kinch CD, Ibhazehiebo K, Jeong JH, Habibi HR, Kurrasch DM. Low-dose exposure to bisphenol $\mathrm{A}$ and replacement bisphenol $\mathrm{S}$ induces precocious hypothalamic neurogenesis in embryonic zebrafish. Proc Natl Acad Sci U S A (2015) 112:1475-80. doi:10.1073/pnas.1417731112

92. Kundakovic M, Gudsnuk K, Franks B, Madrid J, Miller RL, Perera FP, et al. Sex-specific epigenetic disruption and behavioral changes following low-dose in utero bisphenol A exposure. Proc Natl Acad Sci U S A (2013) 110:9956-61. doi:10.1073/pnas.1214056110

93. Wolstenholme JT, Rissman EF, Connelly JJ. The role of bisphenol A in shaping the brain, epigenome and behavior. Horm Behav (2011) 59:296-305. doi:10.1016/j.yhbeh.2010.10.001

94. FAO/WHO. Toxicological and Health Aspects of Bisphenol A: Report of Joint FAO/WHO Expert Meeting and Report of Stakeholder Meeting on Bisphenol A. World Health Organization (2011).

95. Beronius A, Ruden C, Hakansson H, Hanberg A. Risk to all or none? A comparative analysis of controversies in the health risk assessment of bisphenol A. Reprod Toxicol (2010) 29:132-46. doi:10.1016/j.reprotox.2009.11.007

96. Braun JM, Kalkbrenner AE, Calafat AM, Yolton K, Ye X, Dietrich KN, et al. Impact of early-life bisphenol A exposure on behavior and executive function in children. Pediatrics (2011) 128:873-82. doi:10.1542/peds.2011-1335

97. Sathyanarayana S, Braun JM, Yolton K, Liddy S, Lanphear BP. Case report: high prenatal bisphenol a exposure and infant neonatal neurobehavior. Environ Health Perspect (2011) 119:1170-5. doi:10.1289/ehp.1003064

98. Harley KG, Gunier RB, Kogut K, Johnson C, Bradman A, Calafat AM, et al. Prenatal and early childhood bisphenol A concentrations and behavior in school-aged children. Environ Res (2013) 126:43-50. doi:10.1016/j. envres.2013.06.004

99. Perera F, Nolte EL, Wang Y, Margolis AE, Calafat AM, Wang S, et al. Bisphenol A exposure and symptoms of anxiety and depression among inner city children at 10-12 years of age. Environ Res (2016) 151:195-202. doi:10.1016/j. envres.2016.07.028 
100. Ejaredar M, Lee Y, Roberts DJ, Sauve R, Dewey D. Bisphenol A exposure and children's behavior: a systematic review. J Expo Sci Environ Epidemiol (2017) 27:175-83. doi:10.1038/jes.2016.8

101. Sabatier N, Rowe I, Leng G. Central release of oxytocin and the ventromedial hypothalamus. Biochem Soc Trans (2007) 35:1247-51. doi:10.1042/ BST0351247

102. Insel TR. The challenge of translation in social neuroscience: a review of oxytocin, vasopressin, and affiliative behavior. Neuron (2010) 65:768-79. doi:10.1016/j.neuron.2010.03.005

103. McCarthy MM, Altemus M. Central nervous system actions of oxytocin and modulation of behavior in humans. Mol Med Today (1997) 3:269-75. doi:10.1016/S1357-4310(97)01058-7

104. Wolstenholme JT, Goldsby JA, Rissman EF. Transgenerational effects of prenatal bisphenol A on social recognition. Horm Behav (2013) 64:833-9. doi:10.1016/j.yhbeh.2013.09.007

105. Bjorling-Poulsen M, Andersen HR, Grandjean P. Potential developmental neurotoxicity of pesticides used in Europe. Environ Health (2008) 7:50. doi:10.1186/1476-069X-7-50

106. Rauh VA, Garfinkel R, Perera FP, Andrews HF, Hoepner L, Barr DB, et al. Impact of prenatal chlorpyrifos exposure on neurodevelopment in the first 3 years of life among inner-city children. Pediatrics (2006) 118:e1845-59. doi:10.1542/peds.2006-0338

107. de Cock M, Maas YG, van de Bor M. Does perinatal exposure to endocrine disruptors induce autism spectrum and attention deficit hyperactivity disorders? Rev Acta Paediatr (2012) 101:811-8. doi:10.1111/j.1651-2227.2012.02693.x

108. Venerosi A, Ricceri L, Tait S, Calamandrei G. Sex dimorphic behaviors as markers of neuroendocrine disruption by environmental chemicals: the case of chlorpyrifos. Neurotoxicology (2012) 33:1420-6. doi:10.1016/j.neuro. 2012.08.009

109. Whitten PL, Kudo S, Okubo KK. Isoflavonoids. In: D’Mello JPF, editor. Handbook of Plant and Fungal Toxicants. Boca Raton: CRC Press (1997). p. 117-37.

110. Whitten PL, Naftolin F. Dietary plant estrogens: a biologically active background for estrogen action. In: Hochberg RB, Naftolin F, editors. The New Biology of Steroid Hormones. New York: Raven Press (1991). p. 155-67.

111. Patisaul HB. Dietary phytoestrogens. In: Naz RK, editor. Endocrine Disruptors: Effects on Male and Female Reproductive Systems. Boca Raton: CRC Press (2004). p. 135-73.

112. Patisaul HB. Endocrine disruption by dietary phyto-oestrogens: impact on dimorphic sexual systems and behaviours. Proc Nutr Soc (2016) 76(2):130-44. doi:10.1017/S0029665116000677

113. Jefferson WN, Patisaul HB, Williams CJ. Reproductive consequences of developmental phytoestrogen exposure. Reproduction (2012) 143:247-60. doi:10.1530/REP-11-0369

114. Barrett J. Phytoestrogens. Friends or foes? Environ Health Perspect (1996) 104:478-82. doi:10.1289/ehp. 96104478

115. McCarrison R. The goitrogenic action of soya-bean and ground-nut. Indian J Med Res (1933) 21:179-81.

116. Lephart ED, West T, Weber KS, Rhees RW, Setchell K, Adlercreutz H, et al. Neurobehavioral effects of dietary soy phytoestrogens. Neurotoxicol Teratol (2002) 24:5-16. doi:10.1016/S0892-0362(01)00197-0

117. Simon NG, Kaplan JR, Hu S, Register TC, Adams MR. Increased aggressive behavior and decreased affiliative behavior in adult male monkeys after longterm consumption of diets rich in soy protein and isoflavones. Horm Behav (2004) 45:278-84. doi:10.1016/j.yhbeh.2003.12.005

118. Patisaul HB, Blum A, Luskin JR, Wilson ME. Dietary soy supplements produce opposite effects on anxiety in intact male and female rats in the elevated plusmaze. Behav Neurosci (2005) 119:587-94. doi:10.1037/0735-7044.119.2.587

119. Patisaul HB, Whitten PL, Young L. Regulation of estrogen receptor beta mRNA in the brain: opposite effects of 17 $\beta$-estradiol and the phytoestrogen, coumestrol. Brain Res Mol Brain Res (1999) 67:165-71. doi:10.1016/ S0169-328X(99)00058-3

120. Patisaul HB, Melby M, Whitten PL, Young LJ. Genistein affects ER $\beta$ - but not $\mathrm{ER} \alpha$-dependent gene expression in the hypothalamus. Endocrinology (2002) 143:2189-97. doi:10.1210/endo.143.6.8843

121. Plumari L, Viglietti-Panzica C, Allieri F, Honda S, Harada N, Absil P, et al. Changes in the arginine-vasopressin immunoreactive systems in male mice lacking a functional aromatase gene. JNeuroendocrinol (2002) 14:971-8. doi:10.1046/j.1365-2826.2002.00866.x
122. Han TM, De Vries GJ. Organizational effects of testosterone, estradiol, and dihydrotestosterone on vasopressin mRNA expression in the bed nucleus of the stria terminalis. J Neurobiol (2003) 54:502-10. doi:10.1002/neu.10157

123. Yamamoto Y, Cushing BS, Kramer KM, Epperson PD, Hoffman GE, Carter CS. Neonatal manipulations of oxytocin alter expression of oxytocin and vasopressin immunoreactive cells in the paraventricular nucleus of the hypothalamus in a gender-specific manner. Neuroscience (2004) 125:947-55. doi:10.1016/j.neuroscience.2004.02.028

124. Martin MM, Liu Y, Wang Z. Developmental exposure to a serotonin agonist produces subsequent behavioral and neurochemical changes in the adult male prairie vole. Physiol Behav (2012) 105:529-35. doi:10.1016/j. physbeh.2011.09.015

125. Ahern TH, Young LJ. The impact of early life family structure on adult social attachment, alloparental behavior, and the neuropeptide systems regulating affiliative behaviors in the monogamous prairie vole (Microtus ochrogaster). Front Behav Neurosci (2009) 3:17. doi:10.3389/neuro.08.017.2009

126. Curtis JT, Stowe JR, Wang Z. Differential effects of intraspecific interactions on the striatal dopamine system in social and non-social voles. Neuroscience (2003) 118:1165-73. doi:10.1016/S0306-4522(03)00032-0

127. Lieberwirth C, Liu Y, Jia X, Wang Z. Social isolation impairs adult neurogenesis in the limbic system and alters behaviors in female prairie voles. Horm Behav (2012) 62:357-66. doi:10.1016/j.yhbeh.2012.03.005

128. Roberts RL, Zullo AS, Carter CS. Sexual differentiation in prairie voles: the effects of corticosterone and testosterone. Physiol Behav (1997) 62:1379-83. doi:10.1016/S0031-9384(97)00365-X

129. Lonstein JS, Rood BD, De Vries GJ. Unexpected effects of perinatal gonadal hormone manipulations on sexual differentiation of the extrahypothalamic arginine-vasopressin system in prairie voles. Endocrinology (2005) 146:1559-67. doi:10.1210/en.2004-1315

130. Choleris E, Devidze N, Kavaliers M, Pfaff DW. Steroidal/neuropeptide interactions in hypothalamus and amygdala related to social anxiety. Prog Brain Res (2008) 170:291-303. doi:10.1016/S0079-6123(08)00424-X

131. Choleris E, Gustafsson JA, Korach KS, Muglia LJ, Pfaff DW, Ogawa S. An estrogen-dependent four-gene micronet regulating social recognition: a study with oxytocin and estrogen receptor-alpha and -beta knockout mice. Proc Natl Acad Sci U S A (2003) 100:6192-7. doi:10.1073/pnas.0631699100

132. Patisaul HB, Scordalakes EM, Young LJ, Rissman EF. Oxytocin, but not oxytocin receptor, is regulated by oestrogen receptor beta in the female mouse hypothalamus. J Neuroendocrinol (2003) 15:787-93. doi:10.1046/j.1365-2826.2003.01061.x

133. Nomura M, McKenna E, Korach K, Pfaff D, Ogawa S. Estrogen receptor- $\beta$ regulates transcript levels for oxytocin and arginine vasopressin in the hypothalamic paraventricular nucleus of male mice. Mol Brain Res (2002) 109:84-94. doi:10.1016/S0169-328X(02)00525-9

134. Lund TD, Rovis T, Chung WC, Handa RJ. Novel actions of estrogen receptor-beta on anxiety-related behaviors. Endocrinology (2005) 146: 797-807. doi:10.1210/en.2004-1158

135. Kudwa AE, McGivern RF, Handa RJ. Estrogen receptor beta and oxytocin interact to modulate anxiety-like behavior and neuroendocrine stress reactivity in adult male and female rats. Physiol Behav (2014) 129:287-96. doi:10.1016/j.physbeh.2014.03.004

136. Sullivan AW, Hamilton P, Patisaul HB. Neonatal agonism of ERbeta impairs male reproductive behavior and attractiveness. Horm Behav (2011) 60:185-94. doi:10.1016/j.yhbeh.2011.04.006

137. Cushing BS, Wynne-Edwards KE. Estrogen receptor-alpha distribution in male rodents is associated with social organization. J Comp Neurol (2006) 494:595-605. doi:10.1002/cne.20826

138. Lei K, Cushing BS, Musatov S, Ogawa S, Kramer KM. Estrogen receptor-alpha in the bed nucleus of the stria terminalis regulates social affiliation in male prairie voles (Microtus ochrogaster). PLoS One (2010) 5:e8931. doi:10.1371/ journal.pone.0008931

139. Herman JP, Cullinan WE, Watson SJ. Involvement of the bed nucleus of the stria terminalis in tonic regulation of paraventricular hypothalamic CRH and AVP mRNA expression. J Neuroendocrinol (1994) 6:433-42. doi:10.1111/j. 1365-2826.1994.tb00604.x

140. Dabrowska J, Hazra R, Ahern TH, Guo JD, McDonald AJ, Mascagni F, et al. Neuroanatomical evidence for reciprocal regulation of the corticotrophinreleasing factor and oxytocin systems in the hypothalamus and the bed nucleus of the stria terminalis of the rat: implications for balancing stress 
and affect. Psychoneuroendocrinology (2011) 36:1312-26. doi:10.1016/j. psyneuen.2011.03.003

141. Hiroi R, Lacagnina AF, Hinds LR, Carbone DG, Uht RM, Handa RJ. The androgen metabolite, 5alpha-androstane-3beta,17beta-diol (3beta-diol), activates the oxytocin promoter through an estrogen receptor-beta pathway. Endocrinology (2013) 154:1802-12. doi:10.1210/en.2012-2253

142. Shankar A, Teppala S. Urinary bisphenol A and hypertension in a multiethnic sample of US adults. JEnviron Public Health (2012) 2012:481641. doi:10.1155/2012/481641

143. Melzer D, Rice NE, Lewis C, Henley WE, Galloway TS. Association of urinary bisphenol a concentration with heart disease: evidence from NHANES 2003/06. PLoS One (2010) 5:e8673. doi:10.1371/journal.pone.0008673

144. Han C, Hong YC. Bisphenol A, hypertension, and cardiovascular diseases: epidemiological, laboratory, and clinical trial evidence. Curr Hypertens Rep (2016) 18:11. doi:10.1007/s11906-015-0617-2

145. Sivukhina EV, Jirikowski GF. Magnocellular hypothalamic system and its interaction with the hypothalamo-pituitary-adrenal axis. Steroids (2016) 111:21-8. doi:10.1016/j.steroids.2016.01.008

146. Trudel E, Bourque CW. Circadian modulation of osmoregulated firing in rat supraoptic nucleus neurones. J Neuroendocrinol (2012) 24:577-86. doi:10.1111/j.1365-2826.2012.02298.x

147. Silva MP, Cedraz-Mercez PL, Varanda WA. Effects of nitric oxide on magnocellular neurons of the supraoptic nucleus involve multiple mechanisms. Braz J Med Biol Res (2014) 47:90-100. doi:10.1590/1414-431X2013 3326

148. Gillard ER, Coburn CG, de Leon A, Snissarenko EP, Bauce LG, Pittman QJ, et al. Vasopressin autoreceptors and nitric oxide-dependent glutamate release are required for somatodendritic vasopressin release from rat magnocellular neuroendocrine cells responding to osmotic stimuli. Endocrinology (2007) 148:479-89. doi:10.1210/en.2006-0995

149. Nagyeri G, Valkusz Z, Radacs M, Ocsko T, Hausinger P, Laszlo M, et al. Behavioral and endocrine effects of chronic exposure to low doses of chlorobenzenes in Wistar rats. Neurotoxicol Teratol (2012) 34:9-19. doi:10.1016/j.ntt.2011.09.011

150. Curras-Collazo MC. Nitric oxide signaling as a common target of organohalogens and other neuroendocrine disruptors. J Toxicol Environ Health B Crit $\operatorname{Rev}(2011)$ 14:495-536. doi:10.1080/10937404.2011.578564

151. Martini M, Miceli D, Gotti S, Viglietti-Panzica C, Fissore E, Palanza P, et al. Effects of perinatal administration of bisphenol $\mathrm{A}$ on the neuronal nitric oxide synthase expressing system in the hypothalamus and limbic system of CD1 mice. J Neuroendocrinol (2010) 22:1004-12. doi:10.1111/j.13652826.2010.02043.x

152. Filer D, Patisaul HB, Schug T, Reif D, Thayer K. Test driving ToxCast: endocrine profiling for 1858 chemicals included in phase II. Curr Opin Pharmacol (2014) 19:145-52. doi:10.1016/j.coph.2014.09.021

153. Boverhof DR, Chamberlain MP, Elcombe CR, Gonzalez FJ, Heflich RH, Hernandez LG, et al. Transgenic animal models in toxicology: historical perspectives and future outlook. Toxicol Sci (2011) 121:207-33. doi:10.1093/ toxsci/kfr075

154. Myers JP, vom Saal FS, Akingbemi BT, Arizono K, Belcher S, Colborn T, et al. Why public health agencies cannot depend on good laboratory practices as a criterion for selecting data: the case of bisphenol A. Environ Health Perspect (2009) 117:309-15. doi:10.1289/ehp.0800173

Conflict of Interest Statement: The author declares that the research was conducted in the absence of any commercial or financial relationships that could be construed as a potential conflict of interest.

Copyright $\odot 2017$ Patisaul. This is an open-access article distributed under the terms of the Creative Commons Attribution License (CC BY). The use, distribution or reproduction in other forums is permitted, provided the original author(s) or licensor are credited and that the original publication in this journal is cited, in accordance with accepted academic practice. No use, distribution or reproduction is permitted which does not comply with these terms. 